\title{
SPATIAL DISTRIBUTION OF AN EEL POPULATION (ANGUILLA ANGUILLA L.) IN A SMALL COASTAL CATCHMENT OF NORTHERN BRITTANY (FRANCE). CONSEQUENCES OF HYDRAULIC WORKS.
}

\author{
E. FEUNTEUN (1), A. ACOU (1) (2), J. GUILLOUËT (2), P. LAFFAILLE (1) \\ et A. LEGAULT (2)
}

\begin{abstract}
(1) Laboratoire d'Évolution des Systèmes Naturels et Modifiés, UMR 6553 ECOBIO, Université de Rennes 1, 35042 Rennes Cedex, France.

(2) Fish-Pass, 91 avenue de Saint-Brieuc, 35000 Rennes, France.
\end{abstract}

\begin{abstract}
The Frémur is a $60 \mathrm{~km}^{2}$ catchment of Brittany where many hydraulic works (dams, weirs, gauging structures, etc.) have reduced the recruitment by elvers and glass eels since at least 50 years. In 1992, an eel lift was built on the main dam (14 m high) and in 1996 , two other dams (5 m high) located downstream were equipped with eel passes to improve upstream migration. In 1995, before the construction of the passes, eel population parameters (density, biomass and size distribution) were assessed at the scale of the whole watershed by electrofishing (removal method) in 33 stations. The average biomass was high $\left(19 \mathrm{~g} / \mathrm{m}^{2}\right)$ despite the numerous physical obstructions. However, there was an accumulation of eels downstream many hydraulic works and very low densities immediately upstream. Moreover, downstream the first obstruction, at $2 \mathrm{~km}$ from the sea, the population is dominated by boot lace eels and elvers $(<100 \mathrm{~mm})$, whereas this size class is absent in upstream reaches. These results suggest that the standing capacity of the watershed is not reached and that the population could be enhanced in the next years by the recently installed eel passes.
\end{abstract}

Key-words : Anguilla anguilla, biomass, size distribution, hydraulic work, stock management.

\section{DISTRIBUTION SPATIALE D'UNE POPULATION D'ANGUILLE} (ANGUILLA ANGUILLA L.) DANS UN PETIT BASSIN VERSANT DU NORD DE LA BRETAGNE (FRANCE). CONSÉQUENCES D'AMÉNAGEMENTS HYDRAULIQUES.

\section{RÉSUMÉ}

Le Frémur est un bassin versant côtier de Bretagne de $60 \mathrm{~km}^{2}$ comportant de nombreux aménagements hydrauliques (barrages, chaussées de moulin, stations de jaugeage, etc.) ayant fortement réduit l'accessibilité par les civelles depuis au moins cinquante ans. En 1992, un ascenseur à anguilles a été installé sur le principal barrage 
(14 $\mathrm{m}$ de haut), puis en 1996 deux autres obstacles (5 $\mathrm{m}$ de haut) ont été aménagés plus en aval pour restaurer la libre circulation des anguilles dans le bassin versant. En 1995, avant l'aménagement des passes, l'abondance et la structure de la population sont estimées à l'échelle du bassin versant par pêche électrique dans 33 stations (méthode d'épuisement des stocks). La biomasse moyenne apparaît élevée $\left(19 \mathrm{~g} / \mathrm{m}^{2}\right)$ malgré la présence des obstacles à la migration. Toutefois, on note une accumulation d'anguilles en aval de nombreux aménagements hydrauliques et de très faibles abondances en amont de ces derniers. De plus, à l'aval du premier obstacle, à $2 \mathrm{~km}$ de l'estuaire, la population est dominée par les individus de moins de $100 \mathrm{~mm}$, alors que cette classe de taille est quasiment absente en amont. Ces résultats suggèrent que le potentiel d'accueil du bassin versant n'est sans doute pas atteint et que les biomasses moyennes pourraient augmenter avec l'amélioration des conditions de migration grâce aux passes à poissons.

Mots-clés : Anguilla anguilla, biomasse, structure de taille, aménagement hydraulique, gestion des stocks.

\section{INTRODUCTION}

The Frémur (Figure 1) is a small river of northern Brittany (France) which opens into the Channel next to Saint-Malo. Its catchment covers about $60 \mathrm{~km} 2$ and the overall length of the river and its tributaries is $45 \mathrm{~km}$, comprising $17 \mathrm{~km}$ for the main stream. The slope varies between $0.1 \%$ and $2 \%$ for an average of $0.6 \%$. Despite its small size, the Frémur provides for a wide range of habitats from high velocity streams of the trout zone to lentic waters of the bream zone in downstream areas, man made ponds and reservoirs, wetlands, etc. The total extent of water is roughly 50 ha among which 5 ha of running waters (streams) and 45 ha of still waters (ponds and reservoirs) Therefore, this river appears to be representative of small coastal catchments of Western France.

This natural continuum has been disturbed by several hydraulic works which reduce the average velocity, increase the depths and have conducted the community to be dominated by lentic water species of the bream zone. These works also penalize eel migrations and reduce recruitment by elvers and by yellow eels. About 12 flavour mill weirs were built during the $X V$ th century but nowadays only 3 remain. More recently, at the beginning of the century, a $4 \mathrm{~m}$ high dam was built at $2 \mathrm{~km}$ from the river mouth to provide the council with drinkable water. During World War II, several $5 \mathrm{~m}$ high concrete dams were also built for strategic reasons, a single one remains nowadays. In 1991, a 3 million m3 capacity reservoir was created to provide Saint-Malo for drinkable water : the $14 \mathrm{~m}$ high dam of Bois Joli was equipped with an eel lift to permit elvers to migrate upstream.

In 1993, a short survey by the local fishery authority showed that only 2 to 3000 elvers went past the Bois Joli dam using this lift. The resulting recruitment indice (50 elvers $/ \mathrm{km}^{2} /$ year) is about 10 times lower than those of similar catchments in Brittany, for instance the recruitment is 563 elvers $/ \mathrm{km}^{2} /$ year in the Arguenon, a neighbouring river (LEGAULT, 1994). This abnormally low recruitment indice was possibly due to 2 weirs located downstream the Bois Joli eel lift. Therefore, both these obstacles were equipped with elver passes in 1996.

An interesting question rose from this situation: what are the effects of this kind of equipment on the dynamics and the ecology of eel populations at the scale of whole catchments? If several surveys of elver or eel recruitment are now available (JELLYMAN, 1977 ; MORIARTY, 1986 ; LEGAULT, 1994 ; GASCUEL et al., 1995 ; MARTIN, 1995 ; etc.) only a few studies have related recruitment trends to population dynamics 


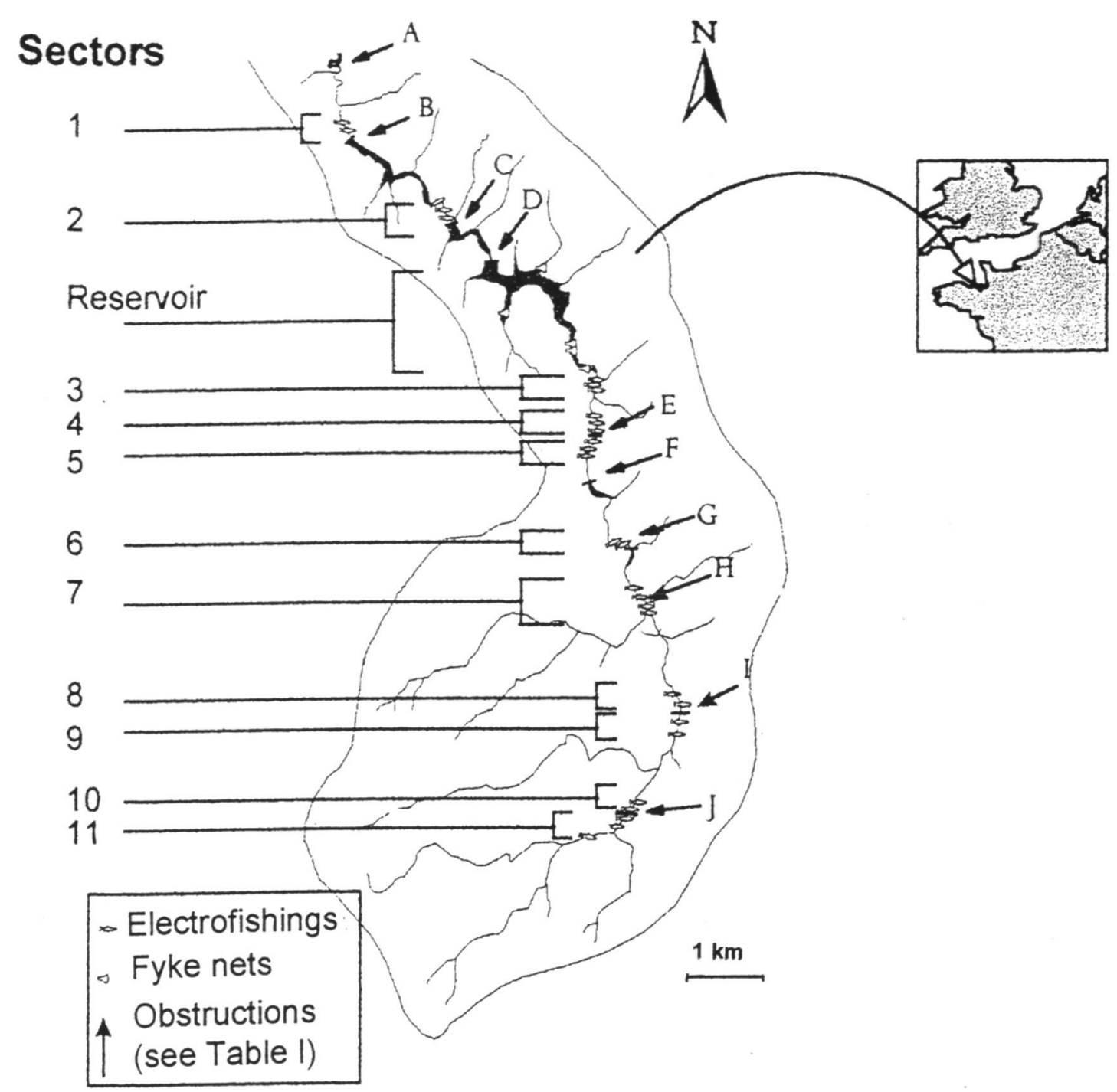

Figure 1

Geographic location of Frémur's watershed, sampling stations and obstructions to upstream migration.

\section{Figure 1}

Situation géographique du bassin versant du Frémur, emplacement des stations de pêche et des obstacles à la migration anadrome.

(VOLLESTAD and JONSON, 1988) and none aimed to conduct a long-term survey of the effects of migration ways restoration on the dynamics of an eel population at the scale of a whole catchment. Such programme started in 1995 on the Fremur and is still conducted by Fish-Pass company and the University of Rennes 1.

The purpose of this paper is to describe the characteristics of the eel population (size structure, density and biomass) in the Fremur's catchment, before the installation of elver passes on the dams. Special emphasis is given to analyse the effects of habitat, of the distance from the sea and of hydraulic works on the spatial distribution of the population. 


\section{MATERIAL AND METHODS}

\section{Characteristics of the catchment}

General details were indicated in the Introduction. In the description hereafter, we distinguish upstream stations ( $>8 \mathrm{~km}$ from the sea) from downstream stations $(<8 \mathrm{~km}$ from the sea).

The average depths (e.g. average maximum depths across a range of stream sections) ranged from $45 \mathrm{~cm}(15-100 \mathrm{~cm})$ in upstream reaches to $105 \mathrm{~cm}(30-150 \mathrm{~cm})$ downstream.

The average widths were comprised between $2.5 \mathrm{~m}(0.5-4.5 \mathrm{~m})$ upstream and $2.9 \mathrm{~m}(1.5-5.5 \mathrm{~m})$ downstream.

Water velocity (maximal velocity across a stream section) ranged between 0 and $0.30 \mathrm{~m} / \mathrm{s}$ according to the river section. No strong water velocity increment was noted from upstream to downstream reaches, probably due to the shortness of the river $(17 \mathrm{~km})$, its morphology (alternating plains and slopes) and to the succession of hydraulic works.

Water was fresh (salinities close to zero) in all the sampled stations. Conductivities averaged $410 \mu \mathrm{s} / \mathrm{cm}$ and ranged from 300 to $530 \mu \mathrm{s} / \mathrm{cm}$. Maximum conductivities were always observed at the outlets of sewage plants.

In $65 \%$ of the stations sampled in the upper reaches of the catchment, substratum was dominated by gravel or by sand, and silt in the others. Beneath the dam of Pont ès Omnès, the substratum was very silty due to mud from agriculture or sewage plants, or clay deposits during marine transgressions in the most downstream reaches.

Vegetation cover was mainly due to riparian helophytes and trees. There was a succession of sections flowing through woodlands, marshes, meadows or cultures (mainly corn) provoking a very heterogeneous vegetation cover.

Many obstructions to eel migration are present in the watershed. The main ones (barrages and weirs) are described in the Introduction. Minor works such as pipes under roads, water flow gauging device, bridge, etc. (see Table I) were also considered as potential temporary obstacles to eel migration.

\section{Eel sampling in running water habitats}

Electrofishings were conducted in $30 \mathrm{~m}$ long stream sections delimited by $3 \mathrm{~mm}$ mesh stop nets. A " heron " (LAMARQUE et al., 1978) apparatus was used and delivered direct current ( 150 to $365 \mathrm{~V}$ and 0.8 to $6 \mathrm{~A}$ ). According to the width and the depth of river section, fishings were either conducted wading in the water or from a boat $(0.09 \%$ of the stations). A standardised depletion method (FEUNTEUN, 1994 ; LAMBERT et al., 1994) was used to assess fish abundance (number and $\mathrm{g} / \mathrm{m}^{2}$ ) using CARLE and STRUB (1978) estimator. A total of 33 river sections were sampled between the estuary and streams located $15 \mathrm{~km}$ upstream in September 1995. In the deepest habitats (ponds and reservoirs) we also used unbaited fyke nets ( $3 \mathrm{~mm}$ mesh), and the results were used to describe the population structure but were not used for stock assessment. 


\section{Table I}

Characteristics of hydraulic works on the Fremur's watershed and effects on upstream migration. $U$ : unpassable obstruction ; TU : temporarily unpassable obstruction and $\mathbf{P}$ : passable obstruction.

\section{Tableau 1}

Caractéristiques des ouvrages hydrauliques du bassin versant du Frémur et effets sur la migration anadrome des anguilles. $U$ : obstacle infranchissable ; TU : temporairement infranchissable et $P$ : franchissable.

\begin{tabular}{|c|c|c|c|c|c|c|}
\hline $\begin{array}{c}N^{\circ} \\
\text { (Flgure 1) }\end{array}$ & Function & $\begin{array}{c}\text { Elevation } \\
\text { (m) }\end{array}$ & $\begin{array}{l}\text { Length } \\
\text { (m) }\end{array}$ & $\begin{array}{l}\text { Water depth } \\
\text { (cm) }\end{array}$ & $\begin{array}{c}\text { Velocity } \\
(\mathbf{m} / \mathbf{s})\end{array}$ & $\begin{array}{l}\text { Effects on } \\
\text { upstream } \\
\text { migration }\end{array}$ \\
\hline A & Disaffected tidal water mill & 0 to 4 & - & $\cdot$ & 0 & $\mathrm{PU}$ \\
\hline $\mathrm{B}$ & Drinkable water reservoir & 6 & - & $0.5 \cdot 10$ & 0 & $\mathrm{PU}$ \\
\hline $\mathrm{C}$ & Strategic dam & 4 & - & $0.5 \cdot 30$ & 0 & $\mathrm{PU}$ \\
\hline$D$ & Drinkable water reservoir & 14 & - & $0-10$ & 0 & $\mathrm{U}$ \\
\hline$E$ & Gauging weir & 1.2 & - & $2-50$ & 0 & $\mathrm{PU}$ \\
\hline$F$ & Disaffected mill weir & 3 & - & $1-50$ & 0 & $\mathrm{PU}$ \\
\hline $\mathrm{G}$ & Disaffected mill weir & 2.5 & - & $1-50$ & 0 & $\mathrm{PU}$ \\
\hline $\mathrm{H}$ & Bridge sill & 0.2 & 12 & $3-40$ & 0.2 & $\mathrm{P}$ \\
\hline 1 & Bridge sill & 0.5 & 6 & $1-20$ & 0.35 & $\mathrm{PU}$ \\
\hline$j$ & Pipes under road & 0.9 & 28 & $1-15$ & 0.40 & $\mathrm{PU}$ \\
\hline
\end{tabular}

\section{Data collected}

Whatever fishing method, eels were measured, weighed and released outside the sampled river section immediately after their capture. Several parameters were measured to analyse eel distribution versus habitat conditions : depth, width, water velocity, vegetation cover, substratum. Considering the shallowness of the stream, capturability was very high ( $p=0.70$ on average). Therefore, the efficiency of the method appeared to be very good for eel (including large eels) sampling as it has been stressed in previous studies (i.e. FEUNTEUN, 1994 ; LAMBERT et al., 1994). The efficiency of the sampling method was tested using fyke nets in still and deep waters, and confirmed the scarcity of eels larger than $760 \mathrm{~mm}$ in the catchment.

\section{RESULTS}

\section{Abundance}

A total of 1080 eels were captured among the 33 electrofished stations and the 5 fyke net stations. The average abundance was $0.51 \mathrm{eel} / \mathrm{m}^{2}$ and $19 \mathrm{~g} / \mathrm{m}^{2}$ (Figure 2). Therefore, in a preliminary analysis, the abundance of the Frémur's eel population seems very high compared to other west European catchments but this is not very surprising considering the shortness of the studied river (FEUNTEUN et al., 1992 ; FEUNTEUN, 1994 ; MORIARTY and DEKKER, 1997). This shows the efficiency of the eel lift, but also indicates that the dams located downstream are not totally impassable for elvers despite their characteristics (see Introduction and Table 1). Nevertheless, the spatial distribution was very heterogeneous : 0 to 1.97 eels $/ \mathrm{m}^{2}$ and 0 to $55 \mathrm{~g} / \mathrm{m}^{2}$ according to the station, and we did not observe an evident diminution of abundance with the distance to the sea which is usually described in longer rivers (ELIE and RIGAUD, 1984 ; TZENG et al., 1995 ; etc.). 


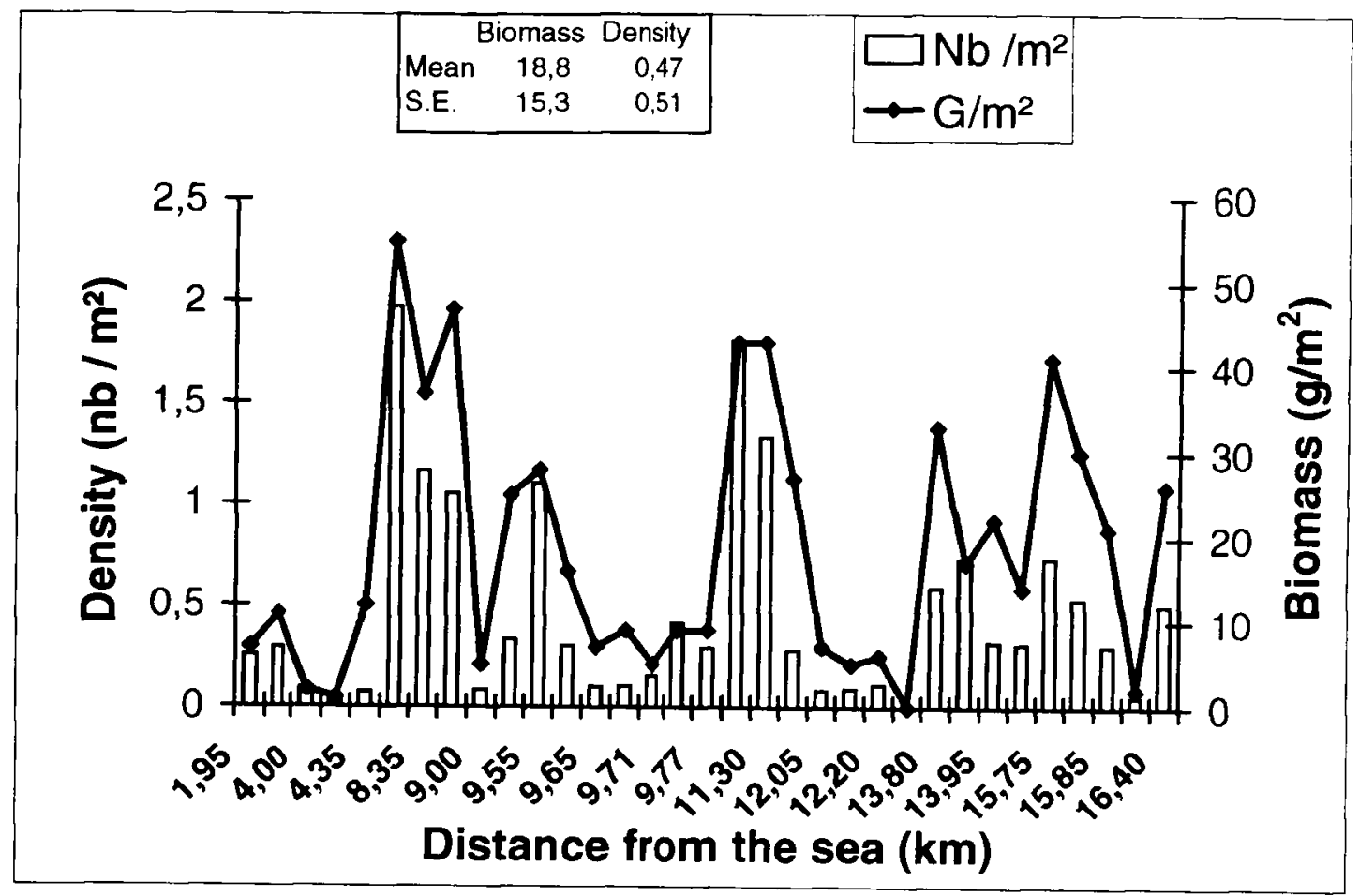

Figure 2

Density and biomass of eel population in the 33 electrofished river sections according to the distance from the river mouth.

Figure 2

Densité et biomasse de la population d'anguilles dans les 33 stations échantillonnées par pêche électrique en fonction de la distance à l'estuaire.

We attempted to explain this heterogeneous distribution and especially why some parts of the river contained low or nil densities and biomass of eels by testing the effects of several habitat variables on population characteristics such as depth, width, distance from the sea, distance from an obstruction, substratum, vegetation cover (not presented here). No significant relation was found. Nevertheless, part of the explanation appeared by analysing eel densities versus the distance to minor hydraulic works like discharge measuring structures, sill of bridges, etc. In most situations, we observed a progressive accumulation of eels from upstream a given obstruction to downstream the next one (Table II). Between two obstructions, habitat parameters also influenced eel distribution (i.e. sector 3, located far from obstructions, contained maximum eel densities). The average biomass immediately downstream the obstructions $(<400 \mathrm{~m})$ is $24.3 \mathrm{~g} / \mathrm{m}^{2}$ $\left(0.66 \mathrm{eel} / \mathrm{m}^{2}\right)$ whereas it is more than three times lower immediately upstream $(<400 \mathrm{~m})$. The difference in density between upstream and downstream reaches of physical obstructions is statistically significant whatever the tested section (T test, Table II). Thus, whole areas, generally (but not always) located closely $(<400 \mathrm{~m})$ upstream obstacles, contained low eel biomass $\left(0\right.$ to $\left.5 \mathrm{~g} / \mathrm{m}^{2}\right)$ despite apparently suitable habitat conditions similar to those noted downstream the obstructions. 


\section{Table II}

Comparison of eel biomass upstream and downstream physical obstructions. T test : Student $t$ test on independent samples. $T$ test paired : Student $t$ test on paired samples.

\section{Tableau II}

Comparaison des biomasses d'anguilles en amont et en aval des obstacles à la migration. T test : test $t$ de Student sur échantillons indépendants. $T$ test paired : test $t$ de Student sur échantillons appariés.

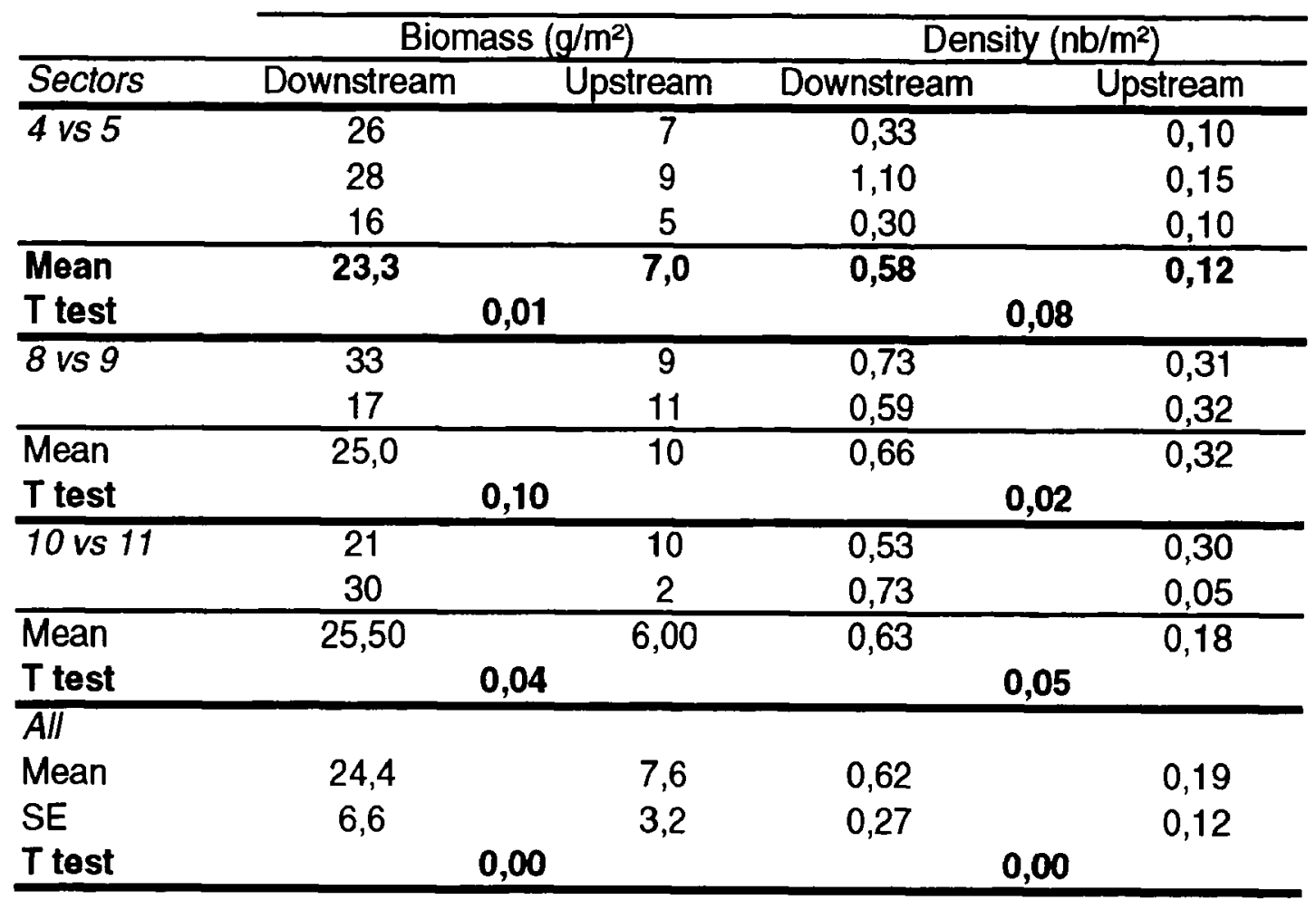

In order to test seasonal variations in the population's spatial distribution, we conducted a sampling campaign in March (unpublished data). Similar concentrations beneath obstructions and diminution of biomass upstream were observed. Therefore, it was assumed that eel distribution was fairly stable throughout a year period. This is rather surprising compared to other studies (i.e. ADAM, 1997) in lakes where yellow eels were described to move from shallow to deep areas according to the season. Further studies are now in progress to clarify this particular point.

\section{Size distribution of population}

The obstruction dams cause to eel migration is confirmed by the analysis of the size distribution of the population (Figure 3). At the scale of the whole watershed, sizes were comprised between $60 \mathrm{~mm}$ and $720 \mathrm{~mm}$. Elvers of $60-80 \mathrm{~mm}$ were strictly confined to sections located downstream the obstruction of Pont Avet. 


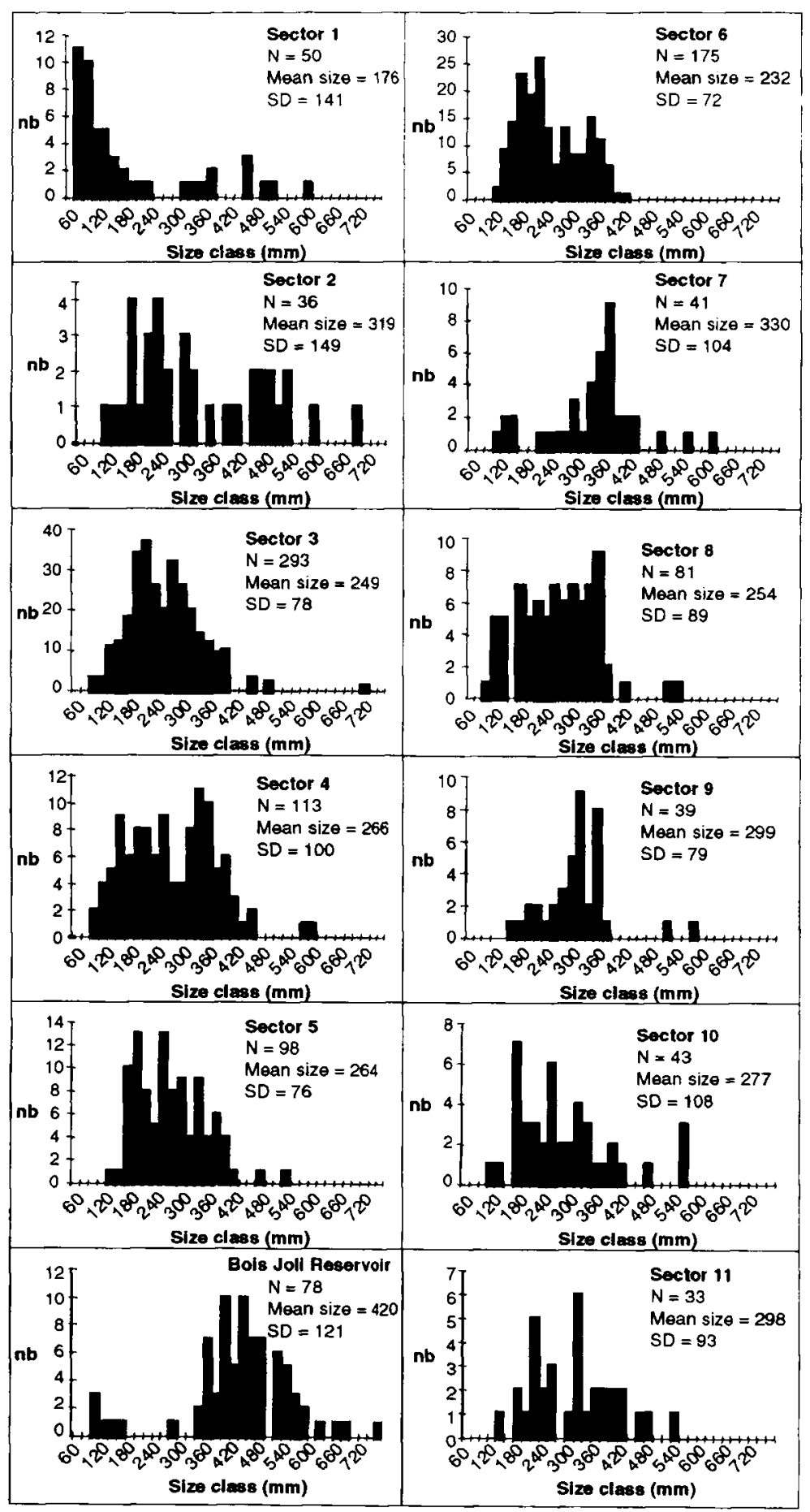

Figure 3

Spatial variation of the structure of the eel population in 12 sampled sectors $(B j$ : fyke net fishings in the reservoir of Bois Joli).

\section{Figure 3}

Variation spatiale de la structure de taille des anguilles capturées dans 12 secteurs de pêche $(B j$ : pêches réalisées aux filets verveux dans la retenue du Bois Joli). 
Apart from these very small elvers $(<80 \mathrm{~mm})$, every size class seemed to be distributed throughout the river, although eels of the year (e.g. eels $<180 \mathrm{~mm}$ ) are scarce and mainly found in downstream areas (Figure 3). However, the presence of this size class in every sampled sectors (including upstream) shows that eels are able to colonize the whole watershed within a year. This confirms other works describing rapid colonization of long rivers within a year. For instance, eels of the year were trapped in eel passes on a tributary of the Loire at more than $250 \mathrm{~km}$ upstream the estuary (LEGAULT, 1996). This suggests that no strong variation of the eel population structure should be expected in the Fremur according solely to the distance from the sea. Nevertheless, strong population structure spatial variation occurred (Table III) : sector 1 is significantly different from all the other sectors due the high proportion (44\%) of $80-100 \mathrm{~mm}$ size classes. The sector of Bois Joli also significantly differs from all the others because of the high proportion of larger size classes ; probably due to a combination of habitat conditions (lake vs running water) and the fishing device (fyke net vs electric fishing). The homogeneity of the other sectors is higher (SiD comprised between 10 and 3).

This suggests a concentration of elvers beneath this dam until they attain a sufficient size to display optimal climbing behaviour and until favourable hydraulic conditions occur enabling to pass over it. Then, the elvers attempt to colonize the whole watershed and the population structure tends to become less heterogeneous.

The irregular but progressive mean size increase of the eels in relation to distance from the sea is thought to be caused by the 10 obstructions which interfere on the migration dynamics.

Table III

Paired comparison of length frequency distribution of eels caught in the 12 different sectors. Kolmogorov Smirnov test for independent samples. Nb SiD : number of significant differences $(99 \%)$.

Tableau III

Comparaison deux à deux des fréquences de taille d'anguilles observées dans les 12 secteurs d'intervention. Test de Kolmogorov Smirnov pour échantillons indépendants. Nb SiD : nombre de différences significatives avec les autres secteurs au seuil de $99 \%$.

\begin{tabular}{ccccccccccccc}
\hline Sector & $\mathbf{1}$ & $\mathbf{2}$ & $\mathbf{3}$ & $\mathbf{4}$ & $\mathbf{5}$ & $\mathbf{6}$ & $\mathbf{7}$ & $\mathbf{8}$ & $\mathbf{9}$ & $\mathbf{1 0}$ & $\mathbf{1 1}$ & $\mathbf{B j}$ \\
\hline $\mathbf{1}$ & $\mathbf{1 , 0 0 0}$ & & & & & & & & & & & \\
$\mathbf{2}$ & 0,000 & 1,000 & & & & & & & & & & \\
$\mathbf{3}$ & 0,000 & 0,004 & 1,000 & & & & & & & & & \\
$\mathbf{4}$ & 0,000 & 0,022 & 0,001 & 1,000 & & & & & & & & \\
$\mathbf{5}$ & 0,000 & 0,012 & 0,412 & 0,156 & 1,000 & & & & & & & \\
$\mathbf{6}$ & 0,000 & 0,002 & 0,010 & 0,003 & 0,002 & 1,000 & & & & & & \\
$\mathbf{7}$ & 0,000 & 0,020 & 0,000 & 0,001 & 0,000 & 0,000 & 1,000 & & & & & \\
$\mathbf{8}$ & 0,000 & 0,010 & 0,382 & 0,324 & 0,427 & 0,026 & 0,000 & 1,000 & & & & \\
$\mathbf{9}$ & 0,000 & 0,049 & 0,000 & 0,018 & 0,007 & 0,000 & 0,009 & 0,017 & 1,000 & & & \\
$\mathbf{1 0}$ & 0,000 & 0,189 & 0,374 & 0,667 & 0,903 & 0,040 & 0,002 & 0,372 & 0,019 & 1,000 & & \\
$\mathbf{1 1}$ & $\mathbf{0 , 0 0 0}$ & 0,230 & 0,005 & 0,207 & 0,084 & 0,002 & 0,039 & 0,096 & 0,325 & 0,039 & 1,000 & \\
Bj & 0,000 & 0,000 & 0,000 & 0,000 & 0,000 & 0,000 & 0,000 & 0,000 & 0,000 & 0,000 & 0,000 & 1,000 \\
\hline Nb SID & 11 & $\mathbf{5}$ & $\mathbf{8}$ & $\mathbf{7}$ & $\mathbf{6}$ & $\mathbf{1 0}$ & $\mathbf{9}$ & $\mathbf{4}$ & $\mathbf{6}$ & $\mathbf{3}$ & $\mathbf{4}$ & 11 \\
\hline
\end{tabular}




\section{CONCLUSIONS - RESEARCH AND MANAGEMENT PERSPECTIVES}

Despite the presence of several hydraulic works which reduce accessibility to upstream zones, the eel population of the Fremur's catchment is very dense compared to other European and French waters. This shows the efficiency of the eel lift constructed on the $14 \mathrm{~m}$ high dam of Bois Joli, but it also shows that even important obstructions such as weirs are passable for elvers under certain hydraulic conditions and mainly for size classes comprised between 100 and $150 \mathrm{~mm}$. The important concentration of eels downstream several hydraulic works indicates that colonization of the catchment is reduced on the Frémur. The colonization of the catchment is mainly due to smaller individuals : most of the works are impassable for eels that exceed $180-200 \mathrm{~mm}$. Consequently, the spatial distribution is very aggregated, which suggests a concentration in the most suitable habitats and/or immediately downstream obstructions and less favourable sites remain unoccupied by eels. Unfortunately, no significant differences were observed between characteristics of stations with and without eels and our attempt to define eel habitat suitability index has to be pursued on a wider range of samples. Such investigation has scarcely been conducted yet (KLEIN-BRETELER, 1997). So, although high average abundances were recorded at the scale of the watershed, the eel stock of Fremur's catchment could probably be enhanced under normal recruitment conditions. In September 1996, eel passes were fixed on the two main obstructions located at less than $5 \mathrm{~km}$ from the sea and the relations between recruitment and population parameters will thus be assessed.

A mean term study has now started and will be conducted at least until 1999 to analyse the consequence of these devices on eel population dynamics and ecology at the scale of the whole catchment. To attain such goals, several experimental devices have been installed : an elver trap and a silver eel trap were built on the dam of Pont ès Omnès at $4 \mathrm{~km}$ from the sea. They were carefully designed to capture every ascending and descending migrating eel. Therefore, daily surveys conducted throughout the year should enable us to determine seasonal and yearly fluctuations of migratory fluxes. The latter will be related to biotic and abiotic factors such as temperature, water flow, population and community parameters, etc. Each year, a population assessment, conducted at the scale of the watershed using electric fishing in running shallow waters and fyke nets in deep still habitats (ponds and reservoirs) should also permit us to assess the effects of the devices on recruitment and population characteristics (density, biomass, age and size distribution, mortality, escapement towards the sea, etc.) and spatial distribution (fish-habitat relationship). Each year, 500 to 1000 eels will be marked with PIT tags. This work aims to provide for information about life history of the recaptured eels, either during the fishings or in the silver eel traps. Effects of environmental events on growth, spatial distribution, migration dynamics and physiology will thus be analysed.

This survey could provide for a monitoring methodology which ought to be used in several watersheds distributed at the range of the European eel population. Beside the scientific information it would provide for, such a monitoring could be necessary within the very next years as a reliable data source for a sustainable management of the stock of this declining species (FONTENELLE et al., 1997 ; MORIARTY and DEKKER, 1997).

\section{ACKNOWLEDGEMENTS}

This study was funded by the Ministry of Environment, the Agence de l'Eau Loire Bretagne, the Regional Council of Brittany, the Conseil Supérieur de la Pêche and the Fédération Départementale des Associations Agréées de Pêche et de Protection des Milieux Aquatiques d'Ille et Vilaine. Special thanks to M. VERDIER, the President of the latter institution. 


\section{REFERENCES}

ADAM G., 1997. L'anguille européenne (Anguilla anguilla L. 1758) : dynamique de la souspopulation du lac de Grand-Lieu en relation avec les facteurs environnementaux et anthropiques. Thèse Université de Toulouse 3, $299 \mathrm{p}$.

CARLE F.L., STRUB M.R., 1978. A new method for estimating population size from removal data. Biometrics, 34, 621-630.

ELIE P., RIGAUD C., 1984. Étude de la population d'anguilles de l'estuaire et du bassin versant de la Vilaine: pêcherie, biologie, écologie. Examen particulier de l'impact du barrage d'Arzal sur la migration anadrome. Rapport CEMAGREF, $174 \mathrm{p}$.

FEUNTEUN E., RIGAUD C., ELIE P., 1992. Le marais doux endigué de BourgneufMachecoul : premiers éléments de connaissance du peuplement piscicole ; relation ichtyofaune-habitat; mise en évidence de problèmes majeurs de gestion. Revue des Sciences de l'Eau, 5 (4), 509-527.

FEUNTEUN E., 1994. Le peuplement piscicole du marais littoral endigué de BourgneufMachecoul (France, Loire-Atlantique). Approche méthodologique pour une analyse quantitative de la distribution spatiale du peuplement piscicole et de la dynamique de certaines de ses populations. Thèse Université de Rennes I, 240 p. + annexes.

FONTENELLE G., FEUNTEUN E., BRIAND C., 1997. French report. In MORIARTY C. and DEKKER W. (eds), Management of European eel fisheries, Irish Fish. Bull., 15, 75-81.

GASCUEL D., FEUNTEUN E., FONTENELLE G., 1995. Seasonal dynamics of estuarine migration in glass eels (Anguilla anguilla). Aquat. Living Ressources, 8 (2), 123133.

JELLYMAN D.J., 1977. Summer upstream migration of juvenile freshwater eels in New Zeland. N. Z. J. Mar. Freshwater Res., 11 (1), 61-71.

KLEIN-BRETELER J., 1997. In EIFAC/ICES working group on eel. ljmuiden, 23-27 September 1996, EIFAC occasional paper $\mathrm{N}^{\circ} 33,18 \mathrm{p}$.

LAMARQUE P.J., ARIGNON J., GOSSET C., 1978. Comparaison des appareils de pêche à l'électricité EPMC et Héron. Bull. Fr. Pêche Piscic., 270, 223-236.

LAMBERT P., FEUNTEUN E., RIGAUD C., 1994. Eel study in freshwater marshes. First analysis of catch probability observed during electric fishing operations. Bull. Fr. Pêche Piscic., 335 (4), 111-122.

LEGAULT A., 1994. Etude préliminaire du recrutement fluvial de l'anguille. Bull. Fr. Pêche Piscic., 335 (4), 33-42.

LEGAULT A., 1996. Colonization dynamics of a catchment area by eel. Characterisation of migrating populations in a free access river. In LECLERC et al. (1996), Proceedings of the second IAHR on habitats hydraulics, ecohydraulics, 200, 89-98.

MARTIN M.H., 1995. The effects of temperature, river flow, and tidal cycles on the onset of glass eel and elver migration into fresh water in the American eel. J. Fish Biol., 46, 891-902.

MORIARTY C., 1986. Riverine migration of young eels Anguilla anguilla (L.). Fisheries Research, 4, 43-58.

MORIARTY C., DEKKER W., (eds), 1997. Management of European eel fisheries. Irish Fish. Bull., 15, $108 \mathrm{p}$.

TZENG W.N., CHENG P.W., LIN F.Y., 1995. Relative abundance, sex ratio and population structure of the Japanese eel Anguilla japonica in the Tanshui River system of northern Taiwan. J. Fish Biol., 46, 183-201.

VOLLESTAD L.A., JONSON B., 1988. A 13-year study of population dynamics and growth of the European eel (Anguilla anguilla) in a Norvegian river : evidence for density dependant mortality, and development of a model for predicting yield. J. Anim. Ecol., 57 (3), 983-997. 